\title{
DIFFERENCES BETWEEN SUPPLIER DEVELOPMENT PROGRAMME OF FOREIGN AND LOCAL MALAYSIAN AUTOMOTIVE SUPPLIERS
}

\author{
KADZRINA ABDUL KADIR \\ HASSAN ALI \\ UUM College of Business \\ Universiti Utara Malaysia
}

\begin{abstract}
Research into supplier development has raised issues on the buyer's relationship with the supplier. A buyer with collaborative relationship would have more interest in supplier development. From the viewpoint of the suppliers, buyers who provided assistance could help the suppliers in developing their capability, a situation that might be particularly relevant in developing and emerging countries. The automotive manufacturers have implemented supplier development programmes for their suppliers, both in developed and developing countries. This raises a question on supplier development programmes in developing countries: How do supplier development programmes differ between a local (Malaysian) supplier and a foreign (non-Malaysian) supplier for Malaysian automakers (buyers)? In this research, interviews were conducted at three supplier organisations, of which one was Australian and two were Malaysian, where all three were suppliers for a Malaysian automaker. This study found that the Malaysian and Australian suppliers differed in supplier categories, customisation versus standardised products and buyer involvement. The study suggests that buyer differences with regard to supplier relationship, supplier commitment, type of product and size of supplier organisation play a role in supplier development.
\end{abstract}

Keywords: Supplier development, buyer-supplier relationship, supplier commitment, automotive industry, Malaysia, Australia.

\section{Background}

Countries such as South Korea and Malaysia embarked on national automotive policies designed to improve the automotive parts production by local suppliers with national automakers having an input in the growth and development of local suppliers (Wad, 2008). However, not all organizations are involved in supplier development. Researchers have noted that organisations which have collaborative relationship with their suppliers would have more interest in supplier development sources. Cusumano and Takeishi (1991), among one of the earliest studies in collaborative relationship, commented on the differences between US and Japanese automakers, highlighting factors such as fewer suppliers per part, more cooperation between automaker and supplier, long contracts, giving suggestions to suppliers and helping suppliers to lower costs that were found in Japanese automakers. 
These types of differences would be referred to as "collaborative supplier relationship" type factors in similar studies in the future. Liker (2004) and Liker and Meier (2007) focused their studies on the extensive training that Toyota implements within the firm, as well as the aspect of the sharing of information and building of trust between supplier and automaker. This suggests that some automakers, through focusing on collaborative relationship, are more often open to supplier development.

Suppliers in developing countries need more assistance from their buyers for development. The Malaysian government has established an environment which protects the automotive industry, and programmes such as supplier development programmes between local automakers and local suppliers have been established to develop the capability of local suppliers. Technology transfer between foreign automotive firms and local firms was also implemented (Abdul Kadir, 2011). The automotivemanufacturershaveimplemented supplier development programmes for their suppliers, both in developed and developing countries. Developed countries include Germany, Switzerland, Australia (Wagner, 2006), United States (Liker \& Choi, 2004; Krause, Handfield \&Tyler, 2007; Handfield, Krause, Scannell \& Monczka, 2000) and Japan (Sako, 2004; Liker \& Choi, 2004). In addition, supplier development programmes have been implemented by automotive manufacturers in developing countries such as Thailand (Coe, Hess, Yeung, Dicken \& Henderson, 2004), India (Ivarsson \& Alvstam, 2004; Okada, 2004) and Malaysia (Othman, Mohamad \& Bakar, 2005). With the range of supplier development programmes being implemented in various countries, this raises the question: How do supplier development programmes differ between companies? For example, how would supplier development programmes differ between a local supplier and a foreign supplier of a Malaysian automaker? Therefore, an initial study of a larger project was implemented wherein the objective was to find the similarities and differences between supplier development programmes among local suppliers and foreign suppliers of Malaysian automakers. Through interviews, key respondents from three suppliers of a Malaysian automaker were queried on the implementation of supplier development programmes in their organisations. Two were Malaysian suppliers and one was an Australian supplier.

\section{Literature Review}

Supplier development literature is related in part to literature on supplier relations. Supplier relations that focus on a close and cooperative buyer supplier relationship could lead to activities focusing on developing the supplier. Three streams of literature have been identified that relate to supplier relations, particularly in manufacturing-based industries such as the automotive industry.

The first stream focuses on supplier relationships in the automotive industry. The literature in this area suggests that supplier relationship is a competitive advantage in the automotive industry. Womack, Jones and Roos (1990/2007) introduced the Lean systemofthe Japaneseautomotivecompanies where supplier relationship is an important factor in ensuring the implementation of the Lean production system. Characteristics of the Lean system as noted by the authors include long durations of buyer-supplier relationship, building customised assets for buyers, and suppliers participating as 
part of a network. Cusumano and Takeishi (1991) meanwhile focused on the differences between the Japanese and the US systems and identified supplier relationship being managed differently in these organisations. Lamming (1993) remarked on the supplier segmentation that is in the Lean system, while Sako and Helper (1998) noted the element of trust in supplier relationships. Dyer, Cho and Chu (1998) remarked on the differences in supplier relationship between US, Japanese and Korean automakers.

Another relevant stream of literature focuses on the automotive industry in developing economies, particularly those that formerly or currently implement protectionist policies. The literature overall, on the protectionist policy for the automotive industry in developing countries suggests that the protectionist policy was not a success. Some factors discussed by the researchers are as follows: In China and Korea, Huang (2002) posited that the implementation of industrial policies was a factor; in India, D'Costa (2004) mentioned inefficient suppliers and weak infrastructure as factors; Humphrey (2003) in his work on India and Brazil, mentioned that suppliers that were not developed and inefficient were factors for the failure; in the ASEAN region, Abrenica (1998) stated that protectionist policies let weak companies exist; lastly, in Thailand, Lecler (2002) and Ivarsson and Alvstam (2004) stated that the policies were implemented to attract multinational corporations (MNCs) but local suppliers were not really developed through technology development.

The last stream focuses on supplier relations in general in the literature and one major area focuses on the purchase and supply chain perspective. Ellram (1996) listed supplier selection factors, while the supplier segmentation model was presented by Kraljic (1983) and the supplier segment relationship model was developed by Svensson (2004). This stream also presented the supplier development concept through research such as that by Krause (1999), Krause and Ellram (1997), Handfield et al. (2000), Liker and Choi (2004) and Sanchez-Rodriguez, Hemsworth and Martinez-Lorente (2005). Related to this area was also the concept of strategic sourcing, which includes supplier selection and supplier development (Talluri and Narasimhan, 2004).

For countries, such as Malaysia, which practice protectionist policies, the impact on the local supplier after the markets liberalised is a concern. Researchers have noted that after the markets were liberalised, the impact on the automotive industry's local suppliers had led to situations where local suppliers had to merge with other local suppliers (Tabachnick, 1999), exit the market (Tabachnick, 1999; Humphrey, 2003), be developed by local automakers or MNCs (Humphrey, 2003; Okada, 2004) or could be acquired by MNC/ foreign suppliers (Humphrey, 2003).

Thus for countries which focus on developing the capabilities of both the local buyers and the local suppliers in industries such as the automotive industry, the survival of the local players after market liberalisation is a concern. Therefore, programmes such as supplier development developed between buyers and local suppliers are expected to build the capability of the local players, especially the local suppliers. Research on identifying the differences between supplier development programmes could help identify factors which would enable the development of the capabilities of local suppliers. Therefore, in this paper, the main research 
question focuses on "How do supplier development programmes differ between a local (Malaysian) supplier and a foreign (non-Malaysian) supplier for Malaysian automakers (buyers)?"

\section{Methodology}

Data was gathered through interviews with senior managers and executives of three supplier organizations. These supplier organisations were suppliers for a local automaker (LA) in Malaysia. For this study, these three supplier organisations were selectedbasedon convenienceandavailability, that is organisations which enabled "easy access to data" (Yin, 2003; Ellram, 1996). Ellram (1996) recommends selecting firms that are located nearby and have congenial respondents. Overall, three key respondents were interviewed on their knowledge of the supplier development programme implemented in their organisations and its activities. Interviews ended when no new information seemed to be collected as this showed that data saturation point (Glaser \& Strauss, 1967) had been reached. Interviews focused on the supplier development programme and its activities, based on the suppliers' knowledge, implemented by the buyer. Two were Malaysian suppliers and one was an Australian supplier.

\section{Findings}

\section{Respondent Profile}

Three supplier respondents were interviewed for this study. These respondents were key informants from three supplier organisations for a LA. To maintain anonymity, the three supplier organisations were given initials unrelated to their actual identities as follows: PS1 (Australian), MPS1 and MPS2 (Malaysian). Figure 1 shows the link between the three supplier organisations and the LA. PS1 supplies automotive parts through its Malaysian subsidiary to the LA.

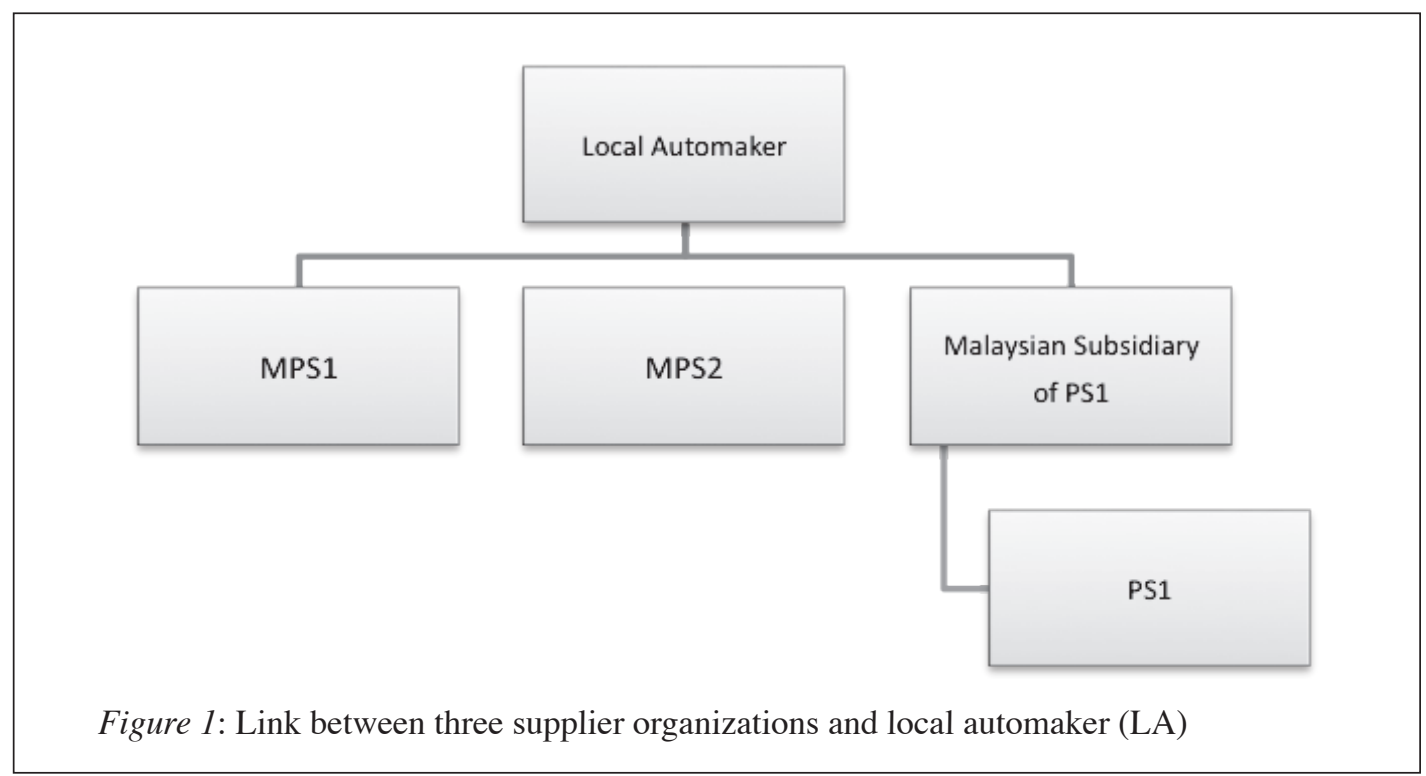




\section{Australian Supplier: PS1}

The following section briefly introduces the Australian automotive industry as a background for PS1, an MNC which has its headquarters in the US, and specialises in the area of painting.

The Australian automotive component industry consists of around 200 firms which supply to the four main automakers: Toyota, Holden-General Motors, Ford and Mitsubishi (Loos \& Coulthard, 2005). The industry exported AUD $\$ 4.6$ billion of automotive products in 2002 (Loos \& Coulthard, 2005), in part due to strong alliances with key automotive and component manufacturers in Europe, Asia and the US (Loos \& Coulthard, 2005). The Australian automotive component industry contrasts with the Malaysian automotive component industry, in that Malaysia's component industry is yet to achieve a high level of exports in automotive products. Thus, information from an Australian automotive component manufacturer would give indicators on how the Malaysian automotive component industry might change in the future if the industry follows the Australian automotive component industry.

\section{Relationship with Australian Buyer}

From the initial study, data showed that PS1 had more buyers from various industries including the automotive industry, when compared with the Malaysian suppliers MPS1 and MPS2. In terms of sales, the automotive industry accounted for less than $30 \%$; therefore, buyers from the automotive industry were not their main customers. PS1 developed a supplierdevelopment programme for its own suppliers. However, from the interview, it was learnt that PS1 did not seem to be involved with its automotive buyers' supplier development programme. PS1 only needed to complete a 'self-assessment' exercise for its buyers to ensure that PS1 was maintaining standards. This suggests that as PS1 was in the paint/coating industry, the buyers from the automotive industry felt that PS1 would have more assistance from PS1's own headquarters in the United States in areas of paint/coating. One implication is that some buyers might not be able to provide the complete development assistance that a supplier might need, especially if the supplier has other buyers outside the automotive industry. Global source system was also mentioned in the interview. The headquarters of an MNC would deal with the headquarters of another MNC when deciding on the selection of a global MNC supplier. Once contracts were agreed, subsidiaries of global MNC suppliers would be awarded contracts in their respective markets.

\section{Supplier Development Programme at PS1}

Another finding from the initial study is that PS1, in its own supplier development programme, categorised its suppliers into three categories. PS1 had a different relationship based on the supplier segment. PS1 explained there were three types of supplier segment. The first segment was suppliers which were MNCs. The second segment was for large, local (Australian) suppliers while the third segment was for foreign suppliers (large, and small and medium enterprise [SME]). Overall, the main criterion for supplier selection in all categories was cost factor.

PS1 explained that not all suppliers were involved in their supplier development 
programme. Suppliers selected for their supplier development programme usually were either large, local suppliers or foreign SME suppliers. These suppliers selected for the programme were then divided into three categories. The first two categories involved large and local suppliers which had either changes in management or changes in location. For these suppliers, there was minimal supplier development assistance. However, for the third category which involved foreign SME suppliers, (for example Chinese suppliers) there was more assistance in supplier development.

PS1 explained that this third category usually involved small firms, which were recently established, that needed guidance and training to upgrade their standards to an acceptable level. Some of these small firms were Asian firms who were interested in supplying to PS1. However, PS1 needed to ensure that these firms have achieved an acceptable level to ensure the viability of the firms in the long run. Thus, both the third and second categories of firms would be involved in supplier development programme run by PS1.

To summarise, findings on PS1 suggest that some companies develop their own supplier development programmes in addition to participating in their buyers' supplier development programme. These companies might have segmented their suppliers based on their buyer-supplier relationship and the need for supplier development assistance. Foreign suppliers are more probable to need assistance compared with MNCs. This study also suggests that some buyers could be categorised by the products that they supplied. In this case, PS1, supplying paint, supplies a standardised product to many buyers both automotive and non-automotive. This suggests that suppliers of standardised products require less collaboration with their buyers, compared to suppliers of customised products. An implication from this situation could be that companies with standardised products would be less inclined to be selected in supplier development programmes with their buyers, as suggested between PS1 and its buyer. In addition, based on the interview, little was mentioned about PS1's experience of the supplier development programme with the LA. This could be due to the fact that PS1 was supplying through its Malaysian subsidiary to the LA.

\section{Malaysian Suppliers: MPS1 and MPS2}

In the previous section, the Australian automotive industry was briefly presented. In Malaysia, the automotive industry is the third largest car market among ASEAN countries (MAI, 2011). The industry structure is based on three car manufacturers, eight car assemblers, nine motor assemblers and more than 800 car component manufacturers and employs more than 300,000 (MAI, 2011) people. Based on the latest census of 2009, sales of motor vehicles was RM13.3 billion while sales of motor vehicle parts and accessories was RM6.9 billion (MAI, 2011).

Two Malaysian suppliers were selected for this research - MPS1 and MPS2. They manufacture parts for two of the Malaysian car manufacturers, with one supplier being a large-size firm (MPS2) while the other (MPS1) is an SME. The large-size firm has been established for more than 20 years while the SME has been established for more than 10 years. From the interviews conducted with respondents of the Malaysian suppliers, findings of both supplier organisations showed similarity and as such, findings from both organisations are compiled to represent Malaysian supplier organisations. 
Both MPS1 and MPS2 participated in supplier development programmes with their Malaysian buyers. Both supplier organisations had been long-term suppliers for their buyer, ranging around 15 years for MPS2 and 10 years for MPS1. Both suppliers produced customised products and worked in collaboration with their buyer for new product development. MPS1 was in the plastic-based industry while MPS2 was in the metal-based industry. The Malaysian buyer comprised a major buyer for both supplier organisations and accounted for $70 \%$ of their sales.

Table 1

Similarities between Foreign and Malaysian Suppliers with Regard to Supplier Development Programmes

\begin{tabular}{lccc}
\hline Issue & Foreign supplier & \multicolumn{2}{c}{ Malaysian suppliers } \\
\hline & PS1 - Australian & MPS1 - & MPS2 - \\
& Multinational & Malaysian SME & Malaysian Large firm \\
Cost criteria is most important & $\checkmark$ & $\checkmark$ & $\checkmark$ \\
$\begin{array}{l}\text { Supplier categories exist } \\
\begin{array}{l}\text { Some supplier segment } \\
\text { relationships exist }\end{array}\end{array}$ & $\checkmark$ & $\checkmark$ & $\checkmark$ \\
\hline
\end{tabular}

Source. Research Study

Both supplier organisations had just started implementing theirown supplier development programmes for their own suppliers. Part of this reason was to ensure the quality of parts that they received from their own suppliers. On their experience of being a participant of their buyer's supplier development programme, MPS1 and MPS2 noted that their buyer was active in ensuring that suppliers participated in the supplier development programme, including providing technical assistant partners to assist suppliers. In comparison with the Australian supplier development programme, MPS1 and MPS2 revealed that the supplier development programme was for all suppliers to the Malaysian buyer. Both supplier organisations had been participants of the supplier development programme for a number of years, nearly as long as their being in a supplier relationship with the Malaysian buyer. MPS1 and MPS2 also made known that the supplier development programme was influenced by Japanese organisations in terms of production systems. This contrasts with the American and European influence in the Australian supplier, PS1. However, when asked for the reason for the existence of the supplier development programmes, both suppliers replied that the programme was to enable the increase in performance of the suppliers, especially in attaining certification of systems. MPS2 related a situation where after working with their technical partner, a Japanese company, for 15 years, MPS2 was able to develop parts on its own without the assistance of its technical partner. This suggests that MPS2 was able to develop its capabilities to the level required for manufacturing Japanese automotive parts. 
To summarise, several differences and though the Australian supplier also supplied similarities were noted between the to the same Malaysian buyer through its Australian supplier development programme subsidiary. Tables 1 and 2 list the differences and the Malaysian supplier development and similarities between the Australian and programme. The differences exist even Malaysian suppliers' supplier development programmes.

Table 2

Differences between Foreign and Malaysian Suppliers with Regard to Supplier Development Programmes

\begin{tabular}{|c|c|c|c|}
\hline \multirow[t]{2}{*}{ Issue } & \multirow{2}{*}{$\begin{array}{c}\text { Foreign Supplier } \\
\text { PS1- } \\
\text { Australian } \\
\text { Multinational }\end{array}$} & \multicolumn{2}{|c|}{ Malaysian Suppliers } \\
\hline & & $\begin{array}{l}\text { MPS1- } \\
\text { Malaysian } \\
\text { SME }\end{array}$ & $\begin{array}{c}\text { MPS2 - } \\
\text { Malaysian } \\
\text { Large Firm }\end{array}$ \\
\hline $\begin{array}{l}\text { Buyer's involvement in } \\
\text { supplier development }\end{array}$ & $\begin{array}{l}\text { Passive - } \\
\text { 'self-assess' }\end{array}$ & $\begin{array}{c}\text { Active } \\
\text { involvement }\end{array}$ & $\begin{array}{l}\text { Provide technical } \\
\text { assistance partner }\end{array}$ \\
\hline $\begin{array}{l}\text { Access to supplier } \\
\text { development }\end{array}$ & $\begin{array}{l}\text { Only for weak } \\
\text { and problematic } \\
\text { suppliers }\end{array}$ & \multicolumn{2}{|c|}{ For all (local) suppliers } \\
\hline $\begin{array}{l}\text { Duration of supplier } \\
\text { development }\end{array}$ & Medium-term & \multicolumn{2}{|c|}{ Long-term } \\
\hline Production system & $\begin{array}{l}\text { American/ } \\
\text { European } \\
\text { influences }\end{array}$ & \multicolumn{2}{|c|}{ Japanese organisations' influences } \\
\hline
\end{tabular}

Source. Research Study

\section{Similarities}

Both supplier development programmes focused on cost as the main criterion in selection of their suppliers. Both programmes also categorised the suppliers into several categories: the Australian programme into three categories, while for the Malaysian programme, the suppliers were divided into local (Malaysian) and foreign (non-
Malaysian) suppliers. Both programmes focused on the objective of increasing the performance of the suppliers, for example, towards attaining certification of systems. Lastly, both programmes suggested that all three supplier organisations had some existing supplier segment relationship. For example, the relationship between buyer and SMEs would be slightly different compared with that of buyer and MNCs. 


\section{Differences}

Overall, however, there seemed to be more differences than similarities when comparing both supplier development programmes. The Australian supplier development programme focused on both local and foreign suppliers while the Malaysian supplier development programme was more focused on local (Malaysian) suppliers only.

Another difference found from this research was that the Australian supplier's supplier development programme with its own (Australian) buyer was focused on 'selfassessment' where the buyer relies on the supplier's own initiative to ensure that standards were being practised. This differs with the situation in Malaysia where the buyer (LA) ensured that its suppliers were being developed through the supplier development programme, through which standards were implemented in the suppliers' organisations. One way to ensure this was through the technical assistance programme initiated by the buyer for its suppliers, with assistance from foreign suppliers from Japan, for example. As the Australian supplier was supplying parts through its Malaysian subsidiary to the LA, the assumption here is that the Australian supplier or its Malaysian subsidiary was not involved in the LA supplier development programme as the programme focuses on Malaysian companies.

Another difference noted between the suppliers was that the Australian supplier had a more cross-sectional customer industry, with the automotive industry only contributing $30 \%$ of its sales. This differed from the Malaysian suppliers, which wholly focused on the automotive industry. This suggests that the Australian supplier would feel less impact if the automotive industry were to suffer a downturn or were badly affected by a recession. The opposite would be felt by the Malaysian suppliers - an industry downturn would badly affect the suppliers as they would have few customers in other industries to turn to.

Another difference between the Australian suppliers and the Malaysian suppliers was that the Australian suppliers could be more active in developing their own suppliers and as such, the supplier development programme implemented within their company was for their own suppliers, rather than in association with their customers - as was the case for the Malaysian suppliers. Thus, the Australian suppliers focused their supplier development programme to develop the capability for weak and problematic suppliers, in fact similar to what the LA was doing for LA's own suppliers. Meanwhile, for the Malaysian suppliers, MPS1 and MPS2, they themselves were just starting to implement a supplier development programme for their own suppliers. This was partly to maintain the quality of parts supplied to the LA.

Another difference was that the supplier development programme implemented by the Australian supplier for its own suppliers was more medium-term. That is, suppliers would be given assistance and development for a certain period, until they were more capable. However, for the Malaysian suppliers, the supplier development programme was longterm. The supplier development programmes for both MPS1 and MPS2 had been implemented for more than 10 years and are still in effect.

Lastly, the influence of the production approach implemented also differed. For the Australian suppliers, the approach was more towards American and/or European 
production systems. This was in contrast with the Japanese production systems' influence in the supplier development programme approach of the Malaysian suppliers. Though this might be related to the history of where the supplier organisations were established (Australia versus Malaysia), many of the same global automotive organisations could be found in both countries, but the number of automotive manufacturing plants might differ.

\section{Relationship between LA and Its Suppliers}

For this research, to have a balanced outlook on the research findings, interviews were also conducted with a LA. A key informant from the LA had echoed the comments on suppliers with regard to selection factors (focusing on cost) as well as on supplier development (to develop suppliers' capabilities, for example through certifications of systems). Among the issues with regard to supplier development programme implementation was the issue of supplier commitment. The LA informant noted that buyers emphasise the commitment of the supplier, both to the buyer as well as to the supplier development programmes. They felt that suppliers who showed a high level of supplier commitment would have a high chance of being selected for new projects. Another issue discussed was that to ensure cost control and cost efficiencies, buyers were in the midst of reducing the total number of suppliers. Instead of an X number of suppliers, suppliers would be grouped into the Tier system. Thus, a LA would now only deal with the suppliers of the major Tier, while the minor Tier suppliers would deal with the major Tier supplier companies. Both MPS1 and MPS2 were Tier 1 suppliers. All of the above issues - supplier commitment, dealing with different levels of suppliers as well as implementing development programmesdealt with buyer-supplier relationships.
Overall, the key informant from the LA emphasised the difficulty of managing relationships:,“... managing technology is easy...managing HR (human resource) is much more difficult..."

Thus, the above section has presented the findings of this research with regard to the differences and similarities between the Australian and the Malaysian suppliers with regard to the implementation of supplier development programmes - the 'how' of the research question for this paper. The next question will discuss possible explanations for the above findings - the 'why'.

\section{Discussion and Implication}

\section{Buyer Differences With Regard to Supplier Relationship}

The interviews suggest that the relationship that buyers have with their suppliers is based on the history and the systems implemented within their organisations. Though more and more companies are implementing the Lean production system, changing from the mass production systems of before, some areas of the Lean production system have been given more attention than others by some companies. For the Lean production system, the development of capable suppliers is an important part and through developing suppliers through the implementation of a supplier development programme, suppliers would be able to develop in tandem with their buyers. As presented in the findings, the influence of the Japanese production systems among Malaysian suppliers suggests that the Lean production system is a key component in the production systems of automotive organisations and thus the supplier development programme, for the long-term is important even though the cost for establishing such a programme is high. 
This research also showed how the different levels of involvement could be taken by the buyers. Some buyers might have a passive involvement with their supplier's development programme while others buyers might take a more active involvement. For example, a long-term involvement in the supplier development programme might suggest an active involvement, while asking suppliers to 'self-assess' might suggest a more passive role in supplier involvement. Krause (1999) noted that buyers in supplier development could play either an active role or a passive role.

The findings also suggest that some buyers might have different points of view on the supplier selection as well as the buyersupplier relationship. Some buyers might prefer the 'cost' outlook and select the best supplier producing the highest quality parts but at the lowest cost. Other buyers might be willing to compromise a little on the cost as long as they could ensure quality parts. And one way to ensure the quality of parts, especially for the future, is through collaborating with their suppliers and developing their capabilities-thus ensuring a lower overall cost in the future. Researchers have noted that differences exist between organisations in different countries as well as those practising different production systems (Cusumano \& Takeishi, 1991; Lamming, 1993; Dyer et al., 1998; Womack et al., 1990/2007).

\section{Customised Versus Standardised Products}

This research revealed the difference in customer focus towards its supplier based on the products. The Australian supplier supplied paint and painting of parts; thus, its products were for the most part standardised products. In contrast, MPS1 and MPS2 provided customised products - their products were based on the product development design given by their customers. This meant that MPS1 and MPS2 worked closely with their buyers to provide the customised parts that their buyers wanted. This also suggests that their buyers might have a reason for ensuring that their suppliers were capable of delivering the parts that were needed. It would also ensure that the capability of these suppliers would be able to be upgraded to a higher level as the LA themselves developed their own capability. Morita and Nakahara (2004) noted the differences between customised and standardised products wherein suppliers with customised products were able to retain their customers longer compared with suppliers of standardised products.

\section{Different Supplier Categories Different Supplier Relationships}

This research also suggests that different supplier categories have different supplier relationships. For the Australian supplier, PS1, its experience showed three different types of supplier relationship. One was between an MNC and another MNC. Though PS1 was a supplier to its automotive customer, both companies were MNCs. As such, there was less involvement at the supplier development activity, thus the 'selfassessment' exercise. Another category of relationship was that between PS1 and its large and local (Australian) suppliers. For this, some involvement of supplier management was given. A more intensive supplier development programme, however, was given to its Chinese suppliers, who were made up of SMEs. For this, PS1 was more involved as it had to increase the capability of these suppliers. 
The level of involvement of the LA with its Malaysian suppliers also suggests intensive levels of involvement - the LA ensured that its Malaysian suppliers were able to develop through its supplier development programme, for example, through the technical assistance programmewithJapanesesuppliers.However, the supplier development programme was provided only for its Malaysian suppliers, suggesting that the LA has less involvement with its non-Malaysian suppliers, which would mostly be MNCs. Svensson (2004), Kraljic (1983) and Lamming (1993) have all commented on supplier segments and the related relationships that suppliers have with their buyers.

\section{Supplier Commitment}

Supplier commitment was more emphasised in the LA and less focused in the other supplier organisations. However, from the action and importance given by the suppliers, supplier commitment is important for both the supplier and the buyers themselves. Buyers need to ensure that suppliers have supplier commitment to ensure that they are willing to follow buyers' needs. For suppliers themselves, involving and following the needs of the customers show their commitment to the buyer and ensure that they will be selected for upcoming projects. Thus, supplier commitment is an important area that is reflected through the implementation and participation of suppliers in the supplier development programme, particularly programmes which have been established for more than a decade.

\section{Limitations}

This research has limitations in that the findings cannot be applied to the population. Other organisations that might have been selected might show more similarities than differences as compared with this study. In addition, the study is restricted to focusing on a single industry, automotive; thus the findings would be more similar to other manufacturing-based industries but might be less applicable to service-based industries. The research has also focused more on the developing country perspective, which would be of benefit to similar countries which target developing the capabilities of the local supplier industry but less relevant to advanced countries with a more skilledsupplier industry.

\section{Conclusion}

Based on the differences between the supplier development programmes of the Australian and the Malaysian suppliers, this study found that suppliers could differ in supplier categories, customisation versus standardised products and buyerinvolvement. The study suggests that buyer differences with regard to supplier relationship, supplier commitment, type of product and size of supplier organisation play a role in supplier development.

\section{Acknowledgements}

The authors gratefully acknowledge the helpful comments of Prof. Rushami Zien Yusoff and an anonymous reviewer on this paper. Parts of this paper were presented at the $6^{\text {th }}$ Australia and New Zealand Academy of Management (ANZAM) Operations, Supply Chain and Services Management Symposium, Queensland, Australia, 8-10 June 2008.

\section{References}

Abdul Kadir, K. (2011). Drivers for supplier development: The local supplier in the Malaysian automotive industry 
(Unpublished doctoral dissertation). Monash University, Melbourne.

Abrenica, J. V. (1998). The Asian automotive industry: Assessing the roles of state and market in the age of global competition. Asian-Pacific Economic Literature, 12(1), 12.

Coe, N. M., Hess, M., Yeung, H. W.-C., Dicken, P., \& Henderson, J. (2004). Globalizing regional development: A global production networks perspective. Transactions of the Institute of British Geographers, 29, 468-484.

Cusumano, M. A., \& Takeishi, A. (1991). Supplier relations and management: A survey of Japanese, Japanesetransplant, and US auto plants. Strategic Management Journal, 12(8), 563-588.

D'Costa, A. P. (2004). Flexible practices for mass production goals: Economic governance in the Indian automobile industry. Industries and Corporate Change, 13(2), 335-367.

Dyer, J. H., Cho, D. S., \& Chu, W. (1998). Strategic supplier segmentation: The next best practice in supply chain management. California Management Review, 40(2), 57-77.

Ellram, L. (1996). The use of the case study method in logistics research. Journal of Business Logistics, 17(2), 93-138.

Glaser, B., \& Strauss, A. (1967). The discovery of Grounded Theory: Strategies of qualitative research. London: Wiedenfeld and Nicholson.

Handfield, R. B., Krause, D. R., Scannell, T. V., \& Monczka, R. M. (2000). Avoid the pitfalls in supplier development. Sloan Management Review, Winter, 37-49.

Huang, Y. (2002). Between two coordination failures: Automotive industrial policy in China with a comparison to Korea. Review of International Political Economy, 9(3), 538-573.

Humphrey, J. (2003). Globalization and supply chain networks: The auto industry in Brazil and India. Global Networks, 3(2), 121-141.

Ivarsson, I., \& Alvstam, C. G. (2004). International technology transfer to local suppliers by Volvo trucks in India. Tijdschrift Voor Economische En Sociale Geografie, 95(1), 27-43.

Kraljic, P. (1983). Purchasing must become supply management. Harvard Business Review, 61, 109-117.

Krause, D., \& Ellram, L. M. (1997). Success factors in supplier development. International Journal of Physical Distribution and Logistics Management, 27, 39-52.

Krause, D. R. (1999). The antecedents of buying firms' efforts to support suppliers. Journal of Operations Management, 17, 205-224.

Krause, D. R., Handfield, R. B., \& Tyler, B. B. (2007). The relationships between supplier development, commitment, social capital accumulation and performance improvement. Journal of Operations Management, 25(2), 528-545.

Lamming, R. (1993). Beyond partnership: Strategies for innovation and lean supply. London: Prentice Hall.

Lecler, Y. (2002). The cluster role in the development of the Thai car industry. International Journal of Urban and Regional Research, 26(4), 799-814.

Liker, J. K. (2004). The Toyota way: 14 management principles from the world's greatest manufacturer. New York: McGraw-Hill.

Liker, J. K., \& Choi, T. Y. (2004). Building deep supplier relationships. Harvard Business Review, 82(12), 104-113. 
Liker, J. K., \& Meier, D. P. (2007). Toyota talent: Developing your people the Toyota way. New York: McGrawHill.

Loos, J. A. A., \& Coulthard, M. (2005). The impact of entrepreneurial orientation on the Australian automotive components industry. Department of Management, Monash University, Working Paper Series, 17/05, 1-17.

MAI.(2011).Malaysianautomotive economy trends and outlook. Malaysian Automotive Institute.

Morita,H.,\&Nakahara,H.(2004).Impacts of the information-technology revolution on Japanese manufacturer-supplier relationships. Journal of the Japanese and International Economics, 18(3), 390-415.

Okada, A. (2004). Skills development and interfirm learning linkages under globalization: Lessons from the Indian automobile industry. World Development, 32(1265-1288).

Othman, S. N., Mohammad, N., \& Bakar, N. A. (2005). Technology transfer for developing suppliers' technological capability. Journal of Technology Management and Entrepreneurship, 3(2), 1-18.

Sako, M. (2004). Supplier development at Honda, Nissan and Toyota: Comparative case studies of organizational capability enhancement. Industries and Corporate Change, 13(2), 281-308.

Sako, M., \& Helper, S. (1998). Determinants of trust in supplier relations: Evidence from automotive industry in Japan and the United States. Journal of Economic Behavior \& Organization, 34(3), 387-417.
Sanchez-Rodriguez, C., Hemsworth, D., \& Martinez-Lorente, A. R. (2005). Supplier development initiatives. Supply Chain Management: An International Journal, 10(4), 289231.

Svensson,G.(2004).Suppliersegmentationin the automotive industry. International Journal of Physical Distribution \& Logistics Management, 34(1), 12-38.

Tabachnick, M. (1999). The impacts of lean production management and continental economic integration on the geography and organizational structure of the Canadian automotive parts industry (Unpublished Master's thesis). Queen's University, Kingston, Ontario, Canada.

Talluri, S., \& Narasimhan, R. (2004). A methodology for strategic sourcing. European Journal of Operational Research, 154, 236-250.

Wad, P. (2008). The development of automotive parts suppliers in Korea and Malaysia: A global value chain perspective. Asia Pacific Business Review, 14(1), 47-64.

Wagner, S. M. (2006). Supplier development practices: An exploratory study. European Journal of Marketing, 40(5/6), 554-571.

Womack, J. P., Jones, D. T., \& Roos, D. (1990/2007). The machine that changed the world: How lean production revolutionized the global car wars. London: Simon and Schuster.

Yin, R. K. (2003). Case study research: Design and methods (3rd ed., Vol. 5). Thousand Oaks, California: Sage Publications. 